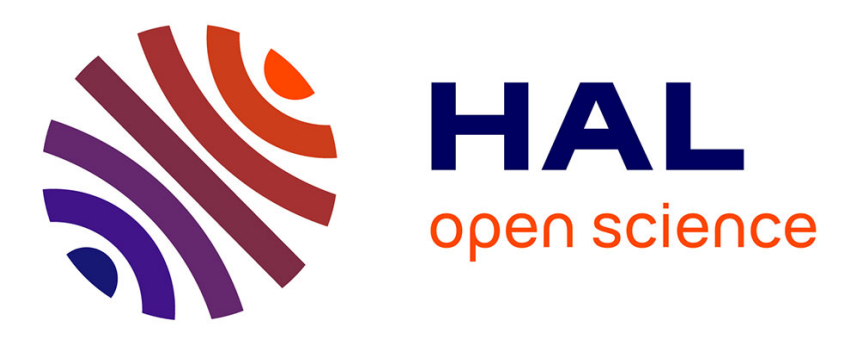

\title{
Grammaticalized uses of the verb ra(a) in Arabic: a Maghrebian specificity?
}

\author{
Catherine Taine-Cheikh
}

\section{To cite this version:}

Catherine Taine-Cheikh. Grammaticalized uses of the verb ra(a) in Arabic: a Maghrebian specificity?. M. Lafkioui. African Arabic: Approaches to Dialectology, De Gruyter, pp.121-159, 2013, Trends in Linguistics $\mathrm{n}^{\circ} 258$. halshs-00982493

\section{HAL Id: halshs-00982493 https://shs.hal.science/halshs-00982493}

Submitted on 24 Apr 2014

HAL is a multi-disciplinary open access archive for the deposit and dissemination of scientific research documents, whether they are published or not. The documents may come from teaching and research institutions in France or abroad, or from public or private research centers.
L'archive ouverte pluridisciplinaire HAL, est destinée au dépôt et à la diffusion de documents scientifiques de niveau recherche, publiés ou non, émanant des établissements d'enseignement et de recherche français ou étrangers, des laboratoires publics ou privés. 


\title{
Grammaticalized uses of the verb ra(a) in Arabic: a Maghrebian specificity?
}

\author{
Catherine TAINE-CHEIKH \\ Lacito (CNRS - Université Paris III Sorbonne Nouvelle)
}

\section{Introduction}

In Arabic, particularly in dialects, cases of verb grammaticalization are highly common. The grammaticalized verbs are used to express temporal, aspectual and modal values, such features often characterizing more or less extended dialectal areas.

This article aims to study the grammaticalization of a verb which originally had the meaning 'to see'. This meaning is preserved in literary Arabic (where its pattern is $\left.r a^{2} \bar{a}\right)$ and in a number of modern dialects, but the word most commonly used in this sense is now šăf. The issues raised when a verb is replaced by another have played an important role in the study of the formation and history of modern dialects. ${ }^{1}$ However, in parallel, there are also issues raised by the uses of grammaticalized $\mathrm{ra}(\mathrm{a})$. When the fixed form of the verb $\mathrm{ra}^{2} \overline{\mathrm{a}}$ is followed by a pronoun affix, it serves, among other functions, to introduce clauses.

In his pioneer work on demonstratives, Fischer (1959) suggests that uses of rā (fixed imperative form) were parallel to the uses of particles stemming from demonstratives derived from hā ou hai. He underlines that this evolution, facilitated by the adoption of the verb šă $f$ for 'to see', was more particularly characteristic of North African dialects.

A few years later, when Marçais described the western dialects in E. I., he identified the presentative $r \bar{a}$ as one of the typical traits of those languages:

"[...] le Maghrib, du Maroc à la Libye, utilise en propre un présentatif de l'idée verbale qui associe l'impératif du verbe 'voir', rāa, aux affixes personnels, avec le sens de 'me voici, te voici, etc.' ou 'voici que je, tu, etc.', ṛānī, ṛāk, ṛāh, ṛāha (ou rạâhi), rạna, rāâkum, rāhum, pour constater la réalité d'un état ou d'une action, dans le présent ou dans le passé, aussi bien devant un verbe à l'accompli ou l'inaccompli), ṛāni jīt 'voici que je suis venu', rậh yebkī 'le voilà qui pleure', qu'en proposition nominale, rāāk mrị̣̂ '(c'est que) tu es malade', rāhum l-temm 'les voilà là-bas'." (1975: 599). ${ }^{2}$

\footnotetext{
${ }^{1}$ For Ferguson (1959: 629), this is one of the fourteen characteristic features of the military koinè, from which all the urban dialects are said to have derived. However Cohen believes that this feature can absolutely not be related to the koinè, given the persistence of $r^{-}{ }^{2} a$ in Andalusian, Maltese and Jewish dialects. The prevalence of $\check{s} \bar{a} f$ in the Bedouin dialects even leads Cohen to an entirely different conclusion: "L'hypothèse peut donc être faite que ce verbe est d'origine post-hilālienne et que son expansion est encore en cours, de façon particulièrement lente dans les parlers juifs qui sont les moins bédouinisés." (1962: 141). [One may therefore posit that this verb has post-Hilalian origins and that its expansion is still ongoing, this expansion being extremely slow in the Jewish varieties which are the least Bedouinized dialects.] On the verb šāf 'to see', its geographic distribution and its etymology, see also respectively Kaye (1976: 157 and sq., 1986) and Bloch 1993.

${ }^{2}$ Maghrebian languages, from Morocco to Libya, are alone in using a presentative of the verbal idea which combines the imperative of the verb riā 'to see' and a person affix, with the meaning 'here I am,
} 
While generalization of $n$ - to mark the first-person singular (through analogy with the plural marker $n$-) can be found in all North African dialects, other common traits are rare. If the grammaticalization of $\mathrm{ra}(\mathrm{a})$ is an African or at least a Maghrebian specificity, it is important to know if this trait is really shared by all Maghrebian dialects and only by them. We will also question if the semantics are always identical from one dialect to the next, or if, as Cohen affirms (1924: 90): "L'emploi de rāa est délicat; il demande à être étudié pour chaque parler". ${ }^{3}$

\section{1. ra(a) in the Maghreb}

$\mathrm{ra}(\mathrm{a})$ (or $\mathrm{ra}(\mathrm{a})$ with the emphatic consonant $r$ ) is sometimes used on its own, ${ }^{4}$ but is more usually followed by a pronoun affix - either a clitic pronoun or, in the 3rd person, the abbreviated form of the independent personal pronoun.

Other relatively minor variations are found. For example, in certain dialects such as Mauritanian Hassāniyya, the nasal consonant $-n-$ which regularly appears in the 1SG has spread to the 1PL, the $2 \mathrm{SG}$ and the 2PL: i.e. $1 \mathrm{SG} r \bar{a}=n i, 2 \mathrm{M} . \mathrm{SG} r \bar{a}-n=a k, 2 \mathrm{~F} . \mathrm{SG}$

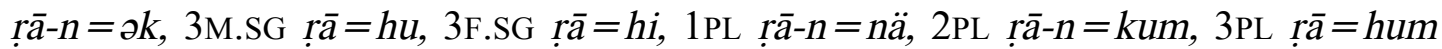
(following the pattern of the negative copula 3M.SG $m \bar{a}-h u$, but 2M.SG $m \bar{a}-n=a k \ldots$..). Among the variants identified by Fisher, there are also the significantly abbreviated forms of the Debdou Jewish dialect (M.SG rāa, F.SG rī, PL rū ), which seem to have been created through analogy with the demonstrative pronouns (ibid.: 190).

Let us now discuss in more detail the uses of $\mathrm{ra}(\mathrm{a})$ in North African dialects.

\section{1. ra(a) in Morocco}

It is not in the Morrocan dialects that the use of ra $\bar{a}$ is thought to be the most frequent, nevertheless, it is in these dialects that the two particles ha and ra have been often compared. In order to understand the specificities acquired by r $r \bar{a}$ in at least part of the Moroccan dialects, the easiest place to begin is with the various possible analyses described by Fisher.

Contrary to Harrell ("The two particles ha and ra have approximately the same meaning 'here is, here are...'", 1962), Colin thought, as early as 1948, that there was a need to make a clear distinction between the particle with deictic origins and the particle with verbal origins:

"Alors que la particule hā- d'origine interjectionnelle, sert à la 'monstration' concrète, rậ- sert à la 'présentation', plus ou moins affective, insistée: 'voici que (actuellement, sûrement, bel et bien, etc)' [...]. La 'présentation' peut porter sur le sujet ou sur le prédicat. La notion présentée peut être non seulement une définition, une qualité, une circonstance, mais aussi un procès: ce n'est donc pas exclusivement un outil de proposition nominale." ${ }^{5}$ (1963: 6-7). ${ }^{6}$

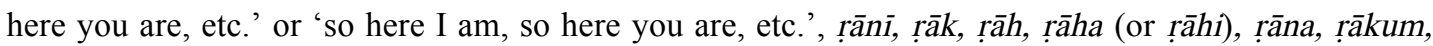
rāhum, to denote the reality of a state or action, in either the present or the past, preceding a verb in either the perfective or the imperfective. rāni jīt 'Here I am, I have come', rânh yebkī 'there he goes crying', or a noun clause rāk mrị̣̂ '(it is that) you are sick', rāâm l-temm 'there they are over there'.

${ }^{3}$ The use of $r \bar{a}$ is complex; it has to be studied for each individual dialect.

${ }^{4}$ As in El-Hâmma in Gabès (Marçais \& Farès 1932: 222).

${ }^{5}$ Whereas the particle $h \bar{a}-$, which originated as an interjection, serves for concrete 'monstration', riā- is used for 'presentation', which can be more or less emotionally charged, insistant: 'and here we (currently, certainly, indeed, etc.) have [...]'. Both subjects and predicates can be 'presented'. The notion presented can be not only a definition, but also a quality, a circumstance, a process: thus it is not a tool restricted to noun clauses.

${ }^{6}$ Colin adds that this particle "est surtout courante dans les régions à substrat berbère; et c'est vraisemblablement dans cette langue qu'il faudra rechercher l'origine de son emploi (cf. berbère
} 
"Deixis, aspect and modality, the particularities of hā- and rāa- in Moroccan Arabic", Caubet's 1992 article defends the same analysis, but further delves into the opposite possibility, only outlined by Colin. Caubet's conclusion well summarizes the differences:

"Avec la particule hā-, le point de départ est une absence; on est dans le domaine de la deixis à l'état pur, du constat: on a une identification directe au centre énonciatif, c'est une valeur de découverte [...].

Par contre, avec rạa, il faut qu'il y ait d'abord une autre valeur, une position décentrée (associée au co-énonciateur) pour, dans un deuxième temps, avoir recentrage sur la bonne valeur (celle de l'énonciateur); on retrouve l'idée de 'forçage' pour amener l'autre sur ses positions." (1992: 149). ${ }^{7}$

The following examples ((1) to (10)), are from Caubet (1993, II: 26 and sq.). Emphasis is the author's-we have only replaced the underlining by bold face. ${ }^{8} \mathrm{We}$ will further refer to Caubet to briefly comment on the examples.

a) Example (1) illustrates focus on the predicative relation, e.g. when the previous speaker's assertion is called into question or not well understood. The reaffirmed term is preceded by riā.

\begin{tabular}{|c|c|c|c|c|}
\hline ḥmod & $r \bar{a}=h$ & $h \bar{u} w a$ & $\partial l=m \bar{u} d \bar{i} r$ & $f=h \bar{a} d=ə s=s \bar{a}^{\Upsilon} a$, \\
\hline Ahme & $r \bar{a}=$ PR.3M.SG & he & $\mathrm{DEF}=$ director.M.SG & in $=$ DEM.PROX $=$ DEF $=$ time \\
\hline$m$ & Sand $=\partial k$ & $m a$ & t-dîri! & \\
\hline NEG & with $=$ PR. $2 \mathrm{SG}$ & NEG & 2.IPFV-can.SG & \\
\hline
\end{tabular}

('C'est Ahmed le directeur en ce moment, tu n'y peux rien!') 'It is Ahmed the director right now, there is nothing you can do about it!'

b) Focus can also be on the predicative marker which, in the next two examples, is the $1 \mathrm{SG}$ pronoun. Here, the pronoun affix agrees with the independent pronoun:

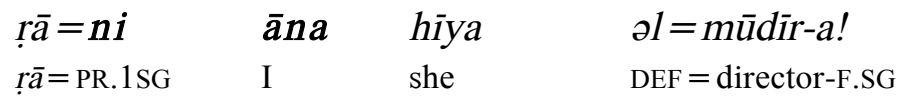

('C'est moi la directrice!') 'I am the Director (F)!'

$$
\begin{aligned}
& \text { əl=mudìr }-a, \quad r a \bar{a}=n i \quad \bar{a} n a \quad h i ̄ y a ! \\
& \mathrm{DEF}=\text { director-F.SG } r \bar{a}=\mathrm{PR} .1 \mathrm{SG} \quad \mathrm{I} \quad \text { she }
\end{aligned}
$$

('La directrice, c'est moi!') 'The director $(\mathrm{F})$ is me!'

When this type of utterance is negated, the negation is often discontinuous and generally surrounds the unit rā-PR. This is the case in the following example, where the reassertion is conveyed by the $1 \mathrm{SG}$ pronoun:

$$
\begin{aligned}
& \text { ma rā }=n i \quad \check{s} \quad \text { āna hìa } \quad l=m \bar{d} \bar{i} r-a ! \\
& \text { NEG } r \bar{a}=\text { PR.1SG NEG I she DEF = director-F.SG }
\end{aligned}
$$

('Ce n'est pas moi la directrice!') 'The director $(\mathrm{F})$ is not me!'

c) The particle rā is used much more often for differenciation than for identification (Caubet 1993, II: 35). It serves to focus on localization, glossable by

\footnotetext{
$\bar{a} q \partial l-, \bar{q} q q \bar{a}-$, etc. [...])" (ibid.: 7) [is especially common in regions with Berber substrates; that is certainly the language where the origins of the particle's use is to be sought] (cf. Berber āqal-, $\bar{a} q q \bar{a}-$, etc. [...]) — an idea to which he returns in a later session of the GLECS (cf. Colin 1966: 174).

${ }^{7}$ With the particle $h \bar{a}-$, the starting point is absence; this is deixis on a very pure level, on the level of stating a fact: there is direct identification at the center of the discourse, denoting discovery [...].

In contrast, with rāa, there must first be some meaning, a decentralized position (associated with the hearer) so that, subsequently, the focus is brought back to the speaker's meaning; this is a way of forcing the hearer to come around to the speaker's own view.

${ }^{8} \mathrm{We}$ are responsible for the morphosyntactic analysis and the English translation and transliteration of most of the examples cited here. We have minimally harmonized transcriptions, whenever there was no risk of altering the meaning. In examples where the meaning in the original is given in English, we have used large quotation marks «...» (e.g. in (12)).
} 
'is indeed localized in reference to X', as in (5) and (6). Here the particle can have actualizing meaning.

$$
\begin{array}{lll}
\Upsilon_{a z z \bar{u} z} & \boldsymbol{r} \bar{a}=\boldsymbol{h} & f=f a ̄ s \\
\text { Azzuz } & r i \bar{a}=\text { PR.3M.SG } & \text { in }=\text { Fez }
\end{array}
$$

('Azzouz est (bien) à Fès en ce moment.') 'Azzouz is (indeed) in Fez at the moment.'

(6) fäyn

$$
\begin{aligned}
& \text { fäyn } \quad r \bar{a}=k \text { ? } \\
& r \bar{a}=\text { PR.2SG } \\
& r \bar{a}=n i \quad f=\text { os }=\text { sțah! }
\end{aligned}
$$
terrace!'

('où es-tu ?' - 'Je suis sur la terrasse!') 'Where are you?' — I'm on the

d) With attributive relations, the particle rā is used only when the located term is clearly determined. Beyond focusing on the relation, the presence of rā can, again, have actualization meaning (Caubet ibid.: 42).

$$
\begin{array}{ll}
r \bar{a}=n \boldsymbol{i} & m r \bar{e} d-a \\
r \bar{a}=\text { PR.1SG } & \text { sick-F.SG }
\end{array}
$$

('Je suis malade.' en ce moment, ou vraiment, ou tu ne vois pas que...) 'I am sick (F).' ('right now', or 'really', or 'can't you see that...')

If the adjectival predicate is fronted, $r \bar{a}-\mathrm{PR}$ follows.
(8) $\quad \boldsymbol{r} \overline{\boldsymbol{a}}=\boldsymbol{h}$
bärəd,
$h \bar{a} d=ə l=x o b z !$
$r \bar{a}=$ PR.3M.SG
cold.M.SG
DEM.PROX $=$ DEF $=$ bread.M.SG

('Il est (vraiment) rassis, ce pain!') 'It is (really) stale, this bread!'

When negation is inserted between rā-PR and the located term, it places emphasis on the latter, see examples (9) and (10). ${ }^{9}$
(9) $\quad r \bar{a}=n i$
ma_ši
tbē $b-a$
$r \bar{a}=\mathrm{PR} .1 \mathrm{SG}$
COP.NEG
doctor-F.SG

('Mais, je ne suis pas médecin, moi!') 'But I am not a doctor, me!'

$\begin{array}{llll}\text { (10) } h \text { hmod } & r \bar{a}=h & \text { ma_ši } & \text { follāḥ! } \\ \text { Ahmed } & r a \bar{a}=\text { PR.3M.SG } & \text { COP.NEG } & \text { farmer-M.SG }\end{array}$

('Ahmed, il n'est pas paysan! Il n'est pas paysan, Ahmed!') 'Ahmed, he is not a farmer! He is not a farmer, Ahmed!'

e) The above examples are all utterances with a non verbal predicate. However, $r \bar{a}$ is also used with verbal predicates. In such cases, "[t]he use of $r \bar{a}$ is especially common when a sort of logical connexion or consequent result is implied", as underlined by Harrell who gives the following example (cf. Caubet 1992: 143):
(11) $\quad$ xud
take.IMP.SG$$
\text { u } \quad r \bar{a}=h
$$

$$
\text { taksi }
$$$$
i \text { iwəșșl }=\curvearrowright k
$$
«take a taxi and he'll get you (SG) there.»
3.IPRV.get.SG $=$ PR.2SG

A similar example was found by Fischer (ibid.: 189) in Colin (1939: 13):
(12) $u=t$ ț
əS $=$ slūgi,
rāa
huunwa
$r \bar{a} \quad$ he
§auñām
and $=$ release. $\mathrm{IMP} . \mathrm{SG} \quad \mathrm{DEF}=$ dog.M.SG
swimmer.M.SG

('und mach dann den Hund los, denn dieser ist ein Schwimmer') 'and then release the dog, because this one is a swimmer'

f) Based on this connective use of rāa, Fischer (ibid:: 193) links it to the use of ārā 'come one! give!'. Although the origins of these two forms are probably distinct, in certain Maghrebian dialects, especially Moroccan, ārā is highly charged emotionally, a trait which makes it almost equivalent to what the particle rāa is used to express elsewhere. Thus, in Tangiers (Marçais 1911: 220, 305) ara is very commonly used (with specific suffixes: arạna and arak), alongside the much rarer

\footnotetext{
${ }^{9}$ With discontinuous negation surrounding rā-PR, as in (4), the focus is on the relationship (Caubet ibid.: 45).
} 
rā meaning 'here is' - more or less synonymous with ha. ara is used as a formula for transition within conversations or stories:
ara $=$ nna
dâba
$1=\dot{g} a r b$
$r \bar{a}=$ PR.1PL
now
$\mathrm{DEF}=$ Morocco.M.SG
('Parlons maintenant du Maroc.') 'Let's now talk about Morocco.'

\section{2. $\mathrm{ra}(\mathrm{a})$ in Algeria}

The use of ra(a) in Algeria has been frequently mentioned in the literature, with values often similar to those identified in Morocco.

Philippe Marçais was the first to note, when comparing the usage and meanings of the two presentatives in an East Algerian dialect, that in Djidjelli (1956: 153) the difference between râh and áu was minimal and that the role of both was similar to that of the preverb $\mathrm{ka} / \mathrm{ku}$ :

"Ils actualisent expressément, en ce qu'ils constatent l'existence dans le présent, en ce qu'ils soulignent l'état actuel d'un sujet qui a accompli, ou qui est en train d'accomplir, ou qui accomplira une action. Mais, à l'inverse du préverbe qui est nécessairement suivi de l'imparfait, les présentatifs peuvent précéder le parfait ou l'imparfait suivant l'époque du procès considéré. Entre rââ et áu la différence est minime. Peut-être peut-on voir dans le premier un présentatif abstrait 'voici qu'il...'; dans le second un présentatif concret 'vois-le qui ...'". ${ }^{10}$

Marçais then analyses the difference (ibid.: 444-5) noting that the second series with the demonstrative marker ha instantiates an actuality, whereas the essential role of râ-PR is as an actualization tool. In parallel, the author notes the emphatic and connective uses of râ, which can potentially be added to its primary actualization function. Hence, in the hypothetical system, râ presents as instantiated, and thus necessary, the consequential relation that links the apodosis clause to the protasis:

$$
\begin{aligned}
& \text { lu-kân dzîd râ=na } \quad n^{\text {O}} \text { oml-u } \quad f \hat{i}=k \\
& \text { if 2.IPRV.keep.up.SG } r \bar{a}=\text { PR.1PL 1.IPRV.do-PL in }=\text { PR.2SG }
\end{aligned}
$$

However, Grand'Henry (1995) notes that in the uses of rā in Algeria, two major language groups can be established. In the Eastern dialects as well as in the Djidjelli dialect, the role of râ is limited, due to the presence of preverbs, and its meanings are similar to those observed in Morocco. However, in the Western sedentary dialects which lack preverbs (Algiers, Cherchell, Tlemcen, Oran), as well as in the Bedouin dialects, the number of tokens is much higher because râ is also frequently used to express simultaneity.

The in-depth study carried out by Boucherit (L'arabe parlé à Alger. Aspects sociolinguistiques et énonciatifs 2002) provides examples which can be used for further comparison with Morocco.

a) Preceding non-verbal predicates, the particle $\mathrm{ra}$ is without any real expressive value: its presence is linked to noun phrases' tendancy to express predicative relations. Even though in the past tense it alternates with kān, it cannot

\footnotetext{
${ }^{10}$ They are explicit actualizers, given that they instantiate existence in the present, in emphasizing the current state of a subject having accomplished, or being in the process of accomplishing, or who will accomplish some action. In contrast to the preverb which must be followed by the imperfect, presentatives may precede the perfect or the imperfect, depending on the time frame of the process under consideration. The difference between râh and áu is minimal. One could possibly consider the first to be an abstract presentative 'there he goes V-ing', and the second a concrete presentative 'see him V-ing'.
} 
be considered identical to the present tense copula as it is not solely used for expressing punctual and impermanent duration (M. Cohen ibid.: 90, Boucherit 2002: 87). See (15) (Boucherit ibid.: 62):
(15) $\quad r a=n i$
$f i=1=$ kuzina
$r a=$ PR.1SG
in $=$ DEF $=$ kitchen.F.SG

('je suis dans la cuisine') 'I am in the kitchen'

ra with expressive meaning does exist in some utterances. However, the expressivity of those expressions is due to the presence of an autonomous personal pronoun before or after ra, and not to the presence of ra. In such cases, the particle is either used as a presentative or as a copula (Boucherit ibid.: 88). ${ }^{11}$
(16) $\quad r a=n i$
ana
$l=$ mudir $-a$
$r a=P R .1 \mathrm{SG} \quad \mathrm{I}$
$\mathrm{DEF}=$ director-F.SG
('C'est moi la directrice') 'It is I the director (F)'

$$
\begin{array}{lll}
\text { ana } & r a=n i & l=\text { mudir- } a \\
\mathrm{I} & r a=\text { PR.1SG } & \text { DEF }=\text { director-F.SG }
\end{array}
$$

('Moi, je suis la directrice') 'Me, I am the director (F)'

The use of the copula seems however relatively more frequent. This is particularly true in negative sentences, where ra- is linked to the negation (Boucherit ibid.: 86):
(18) $m a=r a=h u=\check{s}$
sand $=i$
$\mathrm{NEG}=r a=\mathrm{PR} .3 \mathrm{M} . \mathrm{SG}=\mathrm{NEG}$
at $=$ PR.1.SG

('il n'est pas chez moi') 'He is not at my house'

b) In verbal clauses, ra- is used, among other things, to nuance the fundamental aspectual value of the prefixed or suffixed verbal conjugation, through the expression of "concomitance" [simultaneity]. According to Boucherit (ibid.: 61, 78-80), in such cases the particle ra- bears the double meanings ascribed by David Cohen to the "concomitant" (1989: 92-142): on one hand, neutral meaning, as a simple incidence of the process in reference to the utterance time frame, and on the other hand the expressive meaning of the speaker's implication in the process:
(19) $r a=h$
ixaus
$a^{\Upsilon} l=i$
$r a=$ PR.3M.SG 3M.IPRV.look.SG
for $=$ PR.1.SG

('il me cherche, il est en train de me chercher.') 'He is looking for me, he is in the process of looking for me.'
(20) $r \partial d d-u$
transform.into.PRV-3PL
$m a=r \bar{a}=k=\check{s}$
$1=b \bar{t}$
buwwāl-a ...
$\mathrm{NEG}=r a=\mathrm{PR} .2 \mathrm{M} . \mathrm{SG}=\mathrm{NEG}$
$\mathrm{DEF}=$ room.SG urinal.F.SG
${ }^{\circ}$ tšəmm...

('ils ont transformé la chambre en pissotière... tu ne sens pas...' (= 'tu n'es pas en train de...').) 'They have converted the room into a urinal ... don't you smell...' ( = 'Aren't you starting to...').

c) the use of ra- not being overly constrained, it is not surprising that it shows a great deal of variation. Boucherit's work reveals however certain patterns, such as absence of the use of the complex verbal form (with ra-) in the narrative he examines. The study of the poetic corpus $B \bar{u} q \bar{a} l a \bar{t}$ reveals a change in the frequency and the meanings of ra- over time:

"Dans les textes les plus anciens $(1840,1855)$ la valeur expressive du concomitant prédomine, tandis que dans ceux de 1956 et de 1984 c'est le concomitant neutre qui s'actualise, indiquant peut-être par là que la forme verbale complexe en s'étendant

\footnotetext{
${ }^{11}$ However, statements such as that found in (2) are not attested in Algiers Arabic (Boucherit ibid:: 87).
} 
s'est banalisée et a perdu de sa force expressive" (Boucherit, ibid.: 127-8). ${ }^{12}$

However, the bleaching trend has its limits. Indeed, in the movie ${ }^{\complement}$ Omar Gatlato by Merzak Allouache (1977), the sequences where the complex verb form is the most frequent are the most important part of the story from the narrative point of view (Boucherit, ibid.: 187):

(21) $m a=r \bar{a}=k=\check{s}$

${ }^{\circ}$ tšəmm (...)

$\mathrm{NEG}=r a=\mathrm{PR} \cdot 2 \mathrm{M} \cdot \mathrm{SG}=\mathrm{NEG}$

2.IPRV.feel.M.SG

$r \bar{a}=k \quad{ }^{\imath} t \grave{s} \bar{u} f(\ldots) \quad r a=k \quad$ to ${ }^{\complement} r \partial f(\ldots)$

$r a=$ PR.2M.SG 2.IPRV.see.M.SG $r a=$ PR.2M.SG 2.IPRV.know.M.SG

('(...) tu ne sens pas ? (...) tu vois (...) tu sais ?’) '(...) Don't you feel it? (...) See it (...) Know?'

The use of ra- perpetuates itself in constructions with expressive value. However, one discerns changes over time as ra- is almost exclusively (27/29 tokens) used with specific verbs (internal 'deponent' verbs - perception verbs on one hand, and verbs indicating corporal or intellectual posture on the other). This fact, which is characteristic of dialogues in movies, is not unique: in the sketch "Qaci and Qriqech at a restaurant", almost half of the occurrences (3/7 tokens) can be found with perception verbs meaning 'to hear' and 'to see'. In Algiers, this restriction in use to a small number of verbs particularly related to the personal sphere seems to indicate a weakening in the expressive power of ra-.

\section{3. $\mathrm{ra}(\mathrm{a})$ in Tunisia}

The use of ra- seems much more limited in Tunisia than in Algeria, but several authors have identified examples of Tunisian $\mathrm{ra}(\mathrm{a})$ as a discourse marker.

Among the Marazig Bedouin of Southern Tunisia, Boris (1958: 197) notes that $r \bar{a}$, a corroborative particle which always bears person affixes, has the meaning 'certainly, admittedly':

$$
\begin{array}{ll}
r a \hat{a}=k u m & { }^{\curvearrowright} \check{z} \hat{a}^{\uparrow} \\
r \hat{a}=\text { PR.2PL } & \text { hungry.PL }
\end{array}
$$

('vous avez sûrement faim') 'you must be hungry'

For El-Hâmma of Gabès (Marçais \& Fares 1932: 222), the authors indicate that the presentative râ never has the simple value of a logical copula, as it does in Algeria: it is used to insist on the attribution of a characteristic, to reinforce the effective instantiation of a state or a process.

(23a) $r \hat{a}=h u=m r \hat{u}$

$r \hat{a}=\mathrm{PR} .3 \mathrm{M} \cdot \mathrm{SG}=$ sick.M.SG

('il est bel et bien malade') 'he is indeed sick'

(23b) $r \hat{a}=h i=\check{z} e ̂ t$

$r \hat{a}=$ PR.3F.SG $=$ come.PRV.3F.SG

('elle est bel et bien venue.') 'she did indeed come.'

The authors add that this presentative frequently appears at the head of the apodosis, when the protasis indicates, even if implicitely, hypothesis, condition or irrealis.

The description of the Takroûna dialect is very similar to that of Gabès, where the particle is found in simple sentences as well as in more complex ones with hypothetical meaning (Marçais \& Guiga 1958-1961: 1402-4):

\footnotetext{
${ }^{12}$ In the oldest texts $(1840,1855)$ it is the emotionally charged meaning of the concomitant which is predominant, whereas in those from 1956 and 1984, it is rather the neutrally charged meaning which is instantiated, perhaps thereby indicating a certain degree of semantic bleaching of the complex verb form, through its increasingly frequent and widespread use.
} 
(24)

$$
\begin{aligned}
& m œ=n x a l l i=k=\check{S} \\
& \mathrm{NEG}=1 . \mathrm{IPRV} \cdot 1 \mathrm{let} \cdot \mathrm{SG}=\mathrm{PR} \cdot 2 \mathrm{M} \cdot \mathrm{SG}=\mathrm{NEG} \\
& \underline{r a \hat{a}=h u}=i r \hat{h} h=1=e k \\
& r \hat{a}=\text { PR.3M.SG }=3 \mathrm{M} \cdot \mathrm{IPRV} \text {.get.lost.SG }=\text { for }=\text { PR.2M.SG }
\end{aligned}
$$

$$
\text { thezz }=u=m^{\hat{a}} \hat{a}=k
$$

2.IPRV.take. $. \mathrm{SG}=\mathrm{PR} .3 \mathrm{M} \cdot \mathrm{SG}=$ with $=\mathrm{PR} .2 \mathrm{M} . \mathrm{SG}$

('je ne te laisserai pas l'emporter; (si tu le faisais) tu pourrais le perdre'.) 'I will not let you take it, (if you did so) you might lose it.'

However, the authors also mention a more original use in Takroûna: that of râni, râk, etc., which is added to the end of a sentence in order to corroborate the preceding utterance. In this case, it takes on the meaning of 'here is the fact'; 'this is a fact'; 'yes, certainly' (ibid.: 1404):
(25) iîkđəb
rîa $=h u$
3M.IPRV.lie.SG
$r \hat{a}=$ PR.3M.SG

('il ment et voilà ce qu'il fait.') 'he lies and then goes and does that.'

The marker râa- is also found in Tunis but its use is relatively restricted (Stumme 1896: 145). Gibson (2009: 569) adds that it is used to draw the hearer's attention to the fact that something is obvious (example (26)), whereas the marker hā- brings attention to the presence of the referent (example (27)):
(26) $\quad r \bar{a}=n i$
mazrūb
$r \bar{a}=$ PR.1SG
busy.M.SG

«you see, I'm busy.»

$$
\begin{array}{lll}
h \bar{a}=n i & n a h k i & m^{\varsigma} \bar{a}=k \\
h \bar{a}=\text { PR.1SG } & \text { 1.IPRV.talk.sG } & \text { to }=\text { PR.2sG } \\
\text { «here I am, talking to you» (in particular when the speaker has been }
\end{array}
$$
reproached with not coming)

\section{4. $\mathrm{ra}(\mathrm{a})$ in Libya}

According to what information is available on Libya, occurrences of $r \bar{a}$ are few and far between.

In Tripoli, the use of rā does not seem to be widespread, except as a presentative. ${ }^{13}$ Fischer (ibid.: 191-2) has however noted an example in Stumme's texts (1898: 38, lgn 8) where $r a \overline{~ i s ~ u s e d ~ a s ~ a ~ w a r n i n g: ~}{ }^{14}$
(28) $\quad r \bar{a}=h u m$
ityh-u
$\operatorname{minn}=\mathrm{ek}$
$r \bar{a}=$ PR.3PL 3M.IPRV.fall-PL
out.of $=$ PR.2M.SG

('pa $\beta$ auf, da $\beta$ sie dir nicht verloren') 'watch out that you don't get lost'

Moreover, for Eastern Libyan Arabic, Owens (1984: 147) notes a particular construction (with ma ra + pronoun suffix + illa) that applies only to the $2^{\text {nd }}$ and $3^{\text {rd }}$ persons. The highly expressive formulation reflects a specific stance on the part of the speaker as to the message transmitted:

$$
\begin{array}{ll}
m a=r \bar{a}=k & \text { illa } \\
m a=r \bar{a}=\text { PR.2M.SG } & \text { illa }
\end{array}
$$
«I assume you saw them»

$\begin{array}{llll}m a=r \bar{a}=h & \text { ahmad } & \text { illa } & \text { i-darris } \\ m a=r \bar{a}=\text { PR.3M.SG } & \text { Ahmad } & \text { illa } & \text { 3-IPRV.teach.SG }\end{array}$
«I suppose Ahmad teaches»

The use of rā could however be less restrictive, at least in the east of the country. Cohen (1984: 282) indeed notes that in Benghazi, rā is relatively frequent before verbs with a suffixed or prefixed conjugation, despite the regular use of $g \bar{a}^{\S} \partial d$ for

\footnotetext{
${ }^{13}$ Pereira (2010: 256) only notes such usage.

${ }^{14}$ However, the usual form of warning is rather $\bar{a} r \bar{a}+2^{\text {nd }}$ person suffix.
} 
expressing simultaneity.

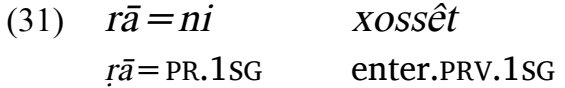
('je suis entré (et me voici)') 'I entered (and here I am)'

\section{5. $\mathrm{ra}(\mathrm{a})$ in Mauritania}

It should be noted that in the Mauritanian Hassāniyya dialect, ra(a) is used as a verb (Taine-Cheikh 1988-98: 730), with the meaning of 'to find' and almost exclusively with the suffixed conjugation (rayt $=u$ 'I found him/it'). In all other cases, $r \bar{a}$ (or its variant arāa-) essentially serves as a discourse marker, as in Eastern Maghreb.

In discourse, the particle is used to draw attention to the instantiation of a state or process. It is used to express actualization or to underline its imminence. It is a means to insist on its established and non contestable aspect, or to warn the hearer, sometimes with threatening undertones. The person pronoun always refers to the subject of the sentence, as in (32a), even when it is not itself the subject, as in (32b, c):
(32a) $1=a x b a ̂ r$
(a) $r a ̂=h i$
$V \hat{\imath}=k$
DEF.news.M.PL
(a) $r \bar{a}=$ PR.3F.SG
from $=$ PR.2SG

'I point out that ... / pay attention, this concerns you'
(a) $r \hat{a}=h u$
žay
(a) $r \bar{a}=$ PR.3M.SG
come.PTCP.M.SG

'I point out, I announce (you M/PL) that he is coming, going'

(32c) (a)râ $=n i$

\section{merị̂}

(a) $r \bar{a}=\mathrm{PR} .1 \mathrm{SG}$

sick.M.SG

'I remind you that..., remember that I am sick'

(a)rāa- is sometimes used to express a logical link between two clauses, emphasizing consequential meaning, or an alternative meaning. In what follows, I have adopted David Cohen's analysis as well as three examples from (1963: 244-6):

\begin{tabular}{|c|c|c|c|c|c|c|c|}
\hline \multirow{2}{*}{\multicolumn{2}{|c|}{$\begin{array}{l}\text { (33a) } h \bar{u} w a \\
\text { he } \\
\text { mən }\end{array}$}} & $g \bar{a} l=l=u$ & \multicolumn{3}{|c|}{${ }^{9}$ ann $=u$} & $\begin{array}{l}\text { lā-boddā } \\
\text { it.is.necessa }\end{array}$ & $\begin{array}{l}l=u \\
y=\text { for }=\text { PR. } 3 \mathrm{M} \cdot \mathrm{SG}\end{array}$ \\
\hline & & i-tamm & mən & yə-t $t^{\Upsilon}$ allam & $b a^{\Upsilon} d$ & $g \bar{a}^{\uparrow}$ & $1=\partial^{\complement} r \grave{r} \bar{b}$ \\
\hline & to & 3M.IPRV-go.on.SG & to & 3M.IPRV-learn.SG & indeed & certainly & $\mathrm{DEF}=i^{\uparrow} r a \bar{b} \cdot \mathrm{M} \cdot \mathrm{SG}$ \\
\hline & $u$ & yo-t $t^{\uparrow}$ allam & & $\check{S} i$ & mon & [11i] & \\
\hline & and & 3M.IPRV-learn.SG & & something & from & [REL] & \\
\hline & gadd & {$[y>-t$} & Sallam & walla & $\operatorname{ar} \bar{a}$ & $=h u$ & lāhi \\
\hline & can.PRV. & $3 \mathrm{M} . \mathrm{SG}$ & QV-learn & I.SG & & PR.3M.SG & FUT \\
\hline & i-sarrh & & & $v=1 \mathrm{c}$ & ХІग & & \\
\hline & 3M.IPRV- & -put.to.graze. $S G=P$ & R.3M. & in $=D E F=$ & a & PL & \\
\hline
\end{tabular}

('il lui dit qu'il fallait qu'il continue... qu'il apprenne avant tout l'i $i^{\uparrow} r a ̄ b$, qu'il se mette à étudier un peu, sans quoi il le mettrait à faire paître les chamelles laitières...') 'He told him he had to go on ... above all to learn the $i^{\text {C }}$ rāb, to start studying a little, if not he would send him out to pasture with the milk camels ...'
(33b) walla $\quad i$-sarrh $=u \quad v=l o=x l o f$
or $\quad 3$ M.IPRV-put.to.graze.SG. $\quad$ in $=$ DEF $=$ milk.camel.F.PL
$V=$ ball $\quad \partial Z=z n a \overline{g i} \quad$ olli
instead.of $=$ [the].place.M.SG.[of $] \quad$ DEF $=$ tributary.M.SG $\quad$ REL
sārəh $=$ höm $\quad$ aṛa $=h u \quad$ oZ $=$ znāgi $\quad i^{\uparrow} \bar{u} d$
herd.PTCP.M.SG $=$ PR.3PL $\quad a r a \bar{a}=$ PR.3M.SG DEF $=$ tributary.M.SG 3 M.IPRV.become.SG




$$
\begin{array}{llll}
\text { axbar } & \text { monn }=u & g \bar{a}^{\Upsilon} & V=\partial l={ }^{\complement} \text { arabiyya } \\
\text { more.learned.[M.SG] } & \text { than= PR.3M.SG } & \text { no.doubt } & \text { in }=\text { DEF=classical.Arabic.F.SG }
\end{array}
$$

('ou il le mettrait à faire paître les chamelles laitières à la place du znāgi qui en était chargé. Et alors le znāgi deviendrait plus fort que lui en arabe classique.') 'Or he would send him out to graze the milk camels instead of the tributary who was responsible for herding them. And then the tributary would become more learned in classical Arabic than he.'

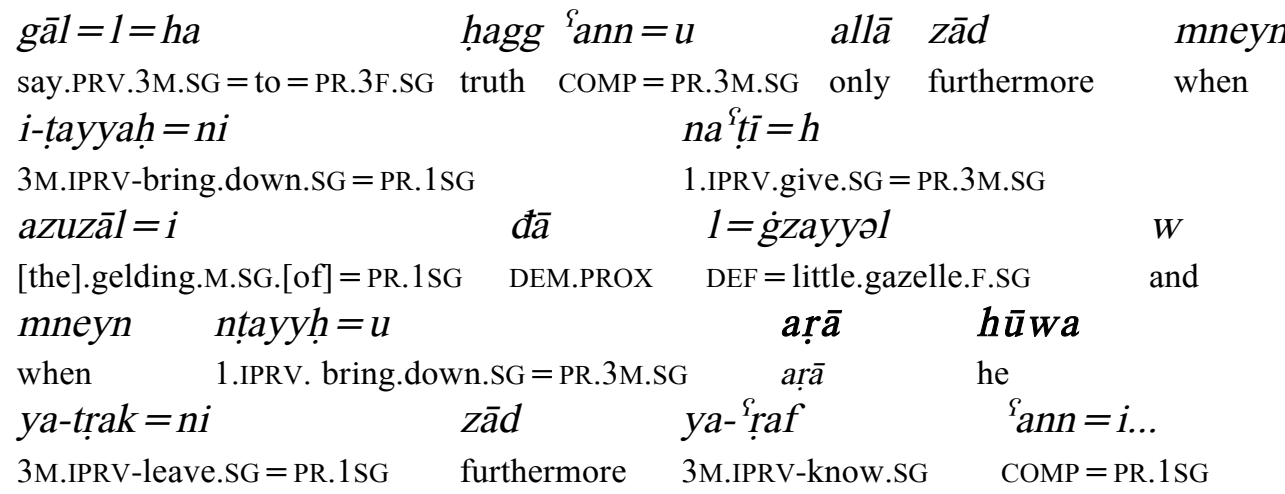

('Le garçon lui dit: Vraiment, s'il arrive à me "coller", je lui donnerai mon cheval hongre que voici, Petite Gazelle, mais si c'est moi qui le "colle", il faut alors qu'il me laisse, il saura...') '[The boy] said to her: Really, if he manages to best me, I will give him my here gelding, Little Gazelle, but if I am the one who bests him, he will then have to leave me alone, he will know...'

The alternate meaning, illustrated in (33a), seems relatively exceptional however and it is the more frequent consequential meaning that is found in the following example (Tauzin 1993: 164, section 3):

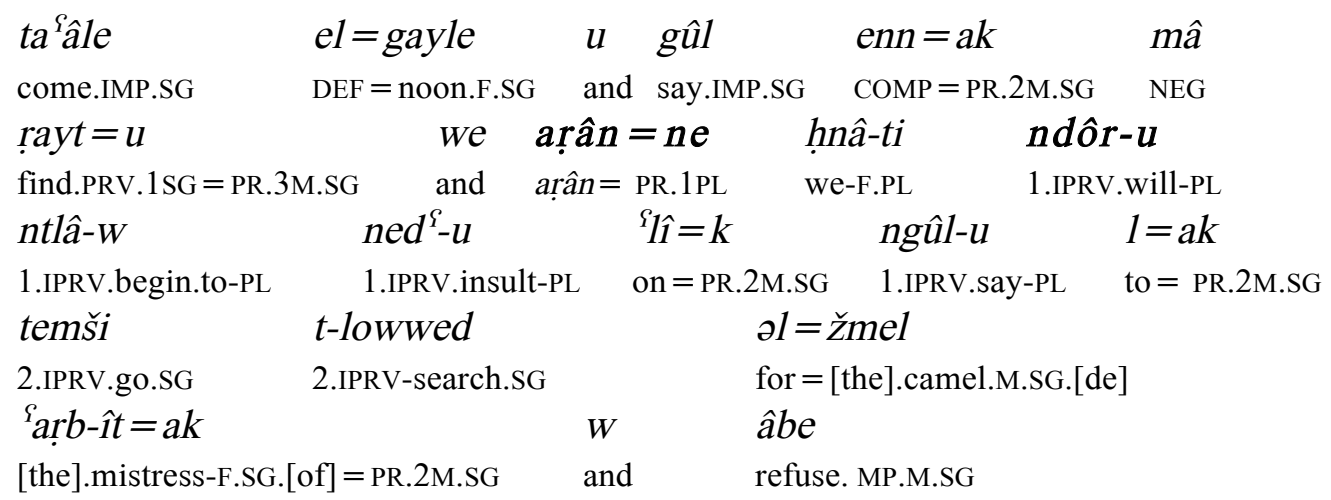

('[...] Reviens à midi, et dis que tu ne l'as pas trouvé. Alors nous, nous nous mettrons à t'insulter, nous te dirons de partir à la recherche du chameau de ta maîtresse et tu refuseras.') '[...] Come back at noon, and say that you did not find it. Then we, we will insult you, we will tell you to go looking for your mistress's camel and you will refuse.'

In order to further the analysis, we will now go back to earlier examples and identify their potential counterparts in Hassāniyya. This will enable us to underline a number of differences.

In comparison to the Moroccan occurrences, it appears that the copular use of $r \bar{a}-$ is impossible in Hassāniyya (see (3) and (4)). However, its use as an insistence particle in (1), (2) and (5) seems to be globally accepted. Thus it seems preferable to paraphrase it by 'I inform you (that)'. ${ }^{15}$

\footnotetext{
${ }^{15}$ In examples (36) and (37), the emphasis is in fact denoted by the focusing structure ... huwwä
} 


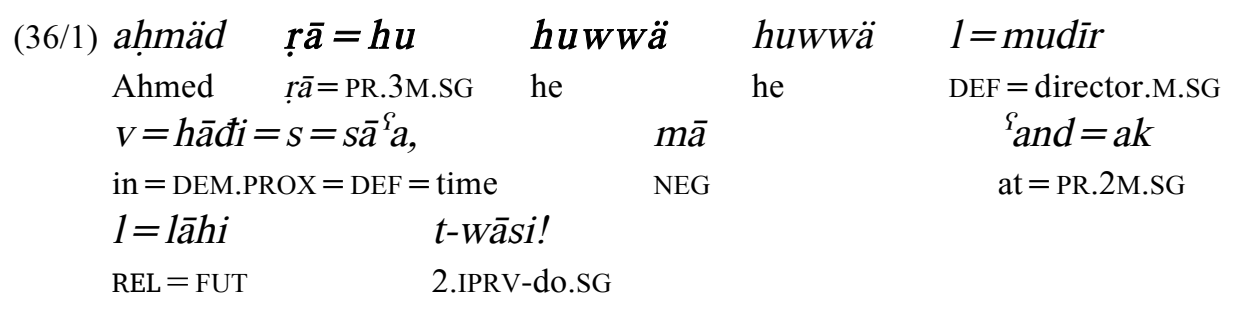

('[Je te signale:] C'est Ahmed le directeur en ce moment, tu n'y peux rien!') '[I inform you:] It is Ahmed who is the director right now, there is nothing you can do about it!'

$(37 / 2)$
rāa-ni
$\bar{a} n a$
hìya
ol=mudira!
$r \bar{a}=$ PR.1M.SG I
she
$\mathrm{DEF}=$ director.F.SG

('[Je te signale:] C'est moi la directrice!') '[I inform you:] I am the Director

(38/5) ${ }^{\complement} a z z \bar{u} z$

$$
r \bar{a}=h u \quad \text { of }=\text { fâs }
$$

Azzouz $\quad r \bar{a}=$ PR.3M.SG in $=$ Fez

('Azzouz [je te signale qu'il] est (bien) à Fès en ce moment') 'Azzouz [I inform you that he] is (indeed) in Fez at the moment'

It is again the same meaning that rā- has in the answer in (40), even if the translation can be used to emphasize the future tense or some conditional nuance. In interrogative clauses, however, r $r \bar{a}$ - only has its meaning of a verb 'to find'.

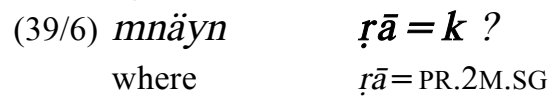

'where did he find you ?' - not: 'Where are you?'

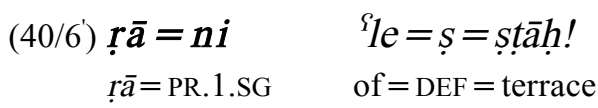

('[if you seek me,] I will be on the terrace') — not: 'Here I am on the terrace'. The discourse value of $r \bar{a}-$ is partially unsteady. It varies according to context, but also according to the relative status of the speaker, as illustrated in (41):
(41) ntûme
arân $=$ kum
māššîn
$\underline{S}=\underline{s u b h}$
you.PL
arân= PR.2.PL
go.PTCP.M.PL
$\mathrm{DEF}=$ tomorrow

i) 'I order you to leave tomorrow' (superior position)

ii) 'I say you will leave tomorrow' (or: 'Surely you will leave tomorrow')

Because the particle rāa- is not a copula, it cannot be negated as it can be in Algiers (cf. (18)). In (42), it is in fact the negation marker mā- followed by the pronoun which serves as copula:
(42) ntûme
arân $=$ kum
$m \bar{a}=k u m$
māššîn
Ș-ṣubh
you.PL $\quad \operatorname{arân}=$ PR.2.PL
$\mathrm{NEG}=\mathrm{PR} .2 \mathrm{PL}$
go.PTCP.M.PL
$\mathrm{DEF}=$ tomorrow

i) 'I order you not to leave tomorrow' (superior position)

ii) 'I assert / I say / I inform you that you will not leave tomorrow' (or: 'Surely you will not leave tomorrow')

Finally, contrary to Algiers Arabic, in Hassāniyya, ṛā- cannot immediately precede a perception verb $\left({ }^{*}\right.$ arān-ak tesma $\left.{ }^{\beta}\right)$. Only the presence of a modal such as yalla 'it has to' cancels this incompatibility. The warning relates then to the necessity of listening, and not to the hearing itself:
(43) $\operatorname{arāan}=a k$
yal! $t=a k$
$\operatorname{arân}=$ PR.2M.SG
it.is necessary $=$ PR.2M.SG
te-sma ${ }^{\text {}}$
'I inform you that you have to hear / I would like that...'

huwwä... / ānä hiyä (a construction not found in Algiers). 
In comparison to what is found in other North African dialects, especially Moroccan and Algerian, Hassāniyya rẹa- is always highly charged emotionally and indicative of a high degree of speaker involvement. This extensive functional and semantic unity is probably linked to the co-existence of a second particle (see below, 2.1.3.).

\section{Particles similar to Maghrebian ra(a)}

(a)ra(a) is not the only particle derived from the verb 'to see' (Classical Arabic $\mathrm{ra}^{2} \overline{\mathrm{a}}$ ), but it is the most frequent in the Maghreb. Let us now focus on other comparable particles, deriving from the same etymon or sharing similar origins.

\subsection{Particles with a pharyngeal consonant}

Several particles, used mainly outside of the Maghreb, are characterized by the presence of a second radical consonant, always a back consonant. The fact that it is mostly a pharyngeal $/ \AA /$ complicates however the search for their origins.

\subsubsection{Southern Arabic peninsula: $r a^{{ }}-$}

In his Datînah glossary, Landberg (1909: 485-501) writes a great deal about $\mathrm{ra}^{\Upsilon}$. He provides numerous examples where the particle, translated most often by 'there it is' or 'that is', is used to emphasize a precise fact or a sudden appearance and is usually used to express the reason behind something, or an event's consequences. Three examples follow (p. 486, 488 and 485):
(44) $r a^{\S}=n \bar{i}$
¿awad
$r a^{Q}=\mathrm{PR} .1 \mathrm{SG}$
sawad

('je suis ${ }^{\complement} \mathrm{A} .$, moi') 'me, I am ${ }^{\complement} \mathrm{A}[\mathrm{wad}]$ '

$$
\begin{array}{lll}
\mathrm{ra}^{\S} & \text { em }=\text { matar } & \text { y-ehđil } \\
r a^{\varsigma} & \text { DEF.rain } & \text { 3M.IPRV-drizzle.SG }
\end{array}
$$

('voilà que la pluie tombe fine') 'There goes the rain falling in showers'
$r a^{\complement}=a k$
fi ard
ऽ̈̈leh
$\mathrm{ra}^{\mathrm{S}}=$ PR.2M.SG in [the].country.[of] ${ }^{\mathrm{S}}$ Olah
('[...] c'est que tu [es] dans le pays des 'Olah') 'That's because you [are] in the country of the Olah'

Landberg considers (ibid: $487-8$ ) that this $\mathrm{ra}^{\S}$ particle, which can take the imperative endings $-i /-u /-e y n$, is a simple variant of the rā used in Africa, the variation being a consequence of a "more guttural prononciation" of the verb $\mathrm{ra}^{2}(\bar{a})$ 'to see'. He underlines that the verb $\mathrm{ra}^{\uparrow}$ is not used in Datînah, but can be found in various Bedouin dialects, in the South-Algerian dialect Ulād Nāil as well as in Syria.

Articles from Vanhove $(1995,2010)$ focus on a region close to Datînah: Yâfi ${ }^{\mathrm{S}}$. The author, who does not identify any major differences on this issue between the two categories of Yemenite Arabic, but who does however underline the differences between Yâfi $^{\complement} \mathrm{ra}^{\complement}$ and Moroccan rā. Contrary to qad, which is comparable to Moroccan Arabic $r \bar{a}$, and is found both within story telling contexts and in spontaneous discourse, Yemenite $\mathrm{ra}^{\S}$ belongs to the deixis system, like Moroccan $h \bar{a}$, and is used only in discourse where it directly introduces an element or event (Vanhove 1995). $\mathrm{ra}^{\complement}$ is mostly used as a marker of discursive hierarchy and clause linkage, but retains its emotionally expressive meaning in all its uses. Hence, when it serves as a copula, "the particle adds an important modal and discursive/pragmatic intensity component to the predicative relation, which can be glossed as 'S is truly, really $\mathrm{P}$ '" (Vanhove 2010: 337-8). 
2.1.2. Middle East: $\operatorname{ar}^{\Upsilon} i$ and its variants

In the Middle East, particles with pharyngeal consonants seem particularly frequent in the Negev and Sinai dialects. They are also frequent in various dialects spoken in Jordan, Palestine and Syria but, within the same area, identified variants display a stop ${ }^{?}$ instead of a pharyngeal ${ }^{?}$.

Bauer notes the forms $\operatorname{har}^{\Upsilon} \bar{u} h$ '[sieh,] dort ist er', har ${ }^{\Upsilon}$ îha '[sieh,] dort ist sie'... in dialects from Palestinian villages, but he also indicates that heraḥ $\bar{u}$ (without ${ }^{\beta}$ ) is heard in Lifta, helehū/helehüte in Bīr Zēt, and that the Bedouins from the surrounding areas say arîh (Bauer 1926: 74).

The two variants were also identified for Syro-Palestinian dialects. Cantineau

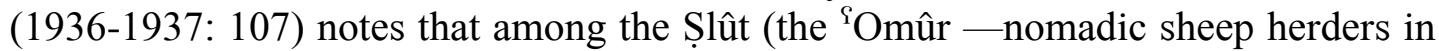
the North of Palmyre) one encounters a presentative with the prefix $h$ - (her ${ }^{\complement} u$ 'there he is', her' $i$ 'there she is'...), whereas Driver (1925: 238) underlines that 'árī has the meaning 'evidently' in Syria-Palestine:

$$
\begin{array}{ll}
{ }^{2} r \bar{i}=k & S \bar{a} \times \overline{1}-n \\
{ }^{a} r \overline{1}=\text { PR.2SG } & \text { feverish.M.PL } \\
\text { «clearly you're feverish» }
\end{array}
$$

It is not proven that the differences in meaning are linked to the differences in form. Palva (1992: 129) indeed identifies examples in al-Balqâ $\hat{a}^{\mathrm{i}}$ (Jordan) where the particle with the prefix ha- has the same meaning, whether the pharyngeal consonant ${ }^{\complement}$ is present, as in $\operatorname{har}^{\Upsilon_{i}}$ in (48), or, as happens very rarely, when it is absent, as in the variant hari:

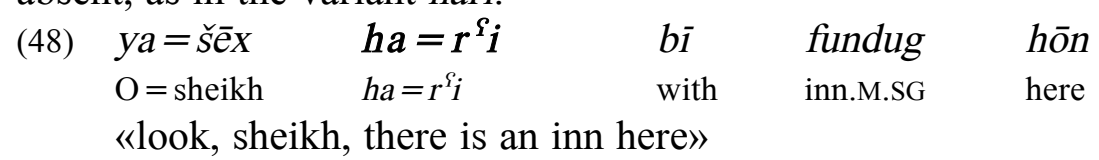

The persistence of forms without the pharyngeal consonant ${ }^{8}$ or with the laryngeal stop ${ }^{?}$ could be the remnants of more ancient forms, before ${ }^{?}$ was replaced by ${ }^{\complement}$. In fact, a majority of authors agree with Landberg and consider that $\mathrm{ra}^{\uparrow}$ derives from the verb * $\mathrm{r}^{2} \overline{\mathrm{a}}$ ' to see'. Stewart (1990: 10, fn 88) strengthens this thesis by giving another example from the same category: $s a^{2} a l>s a^{\Upsilon} a l$ 'to ask'. In contrast, Henkin explores the idea (2010: 135), to which we will return below, of possible confusion between the imperative form ${ }^{*} \mathrm{ra}^{\mathrm{P} a}$ 'to see' and $\mathrm{ra}^{\Upsilon} \mathrm{a}$ 'to shepherd, watch over'.

Whatever the etymology, Negev Arabic is included in the dialects where the particle used always contains ${ }^{S}$, like the Bedouin Dialects of the Northern Sinai Littoral.

In the Negev (Henkin ibid.), the two variants are the invariable form $a r^{\complement}$ and the full imperative form (M.SG $a r^{\complement} i y$, M.PL $a r^{\complement} u W \ldots$...), with constant presentative meaning:

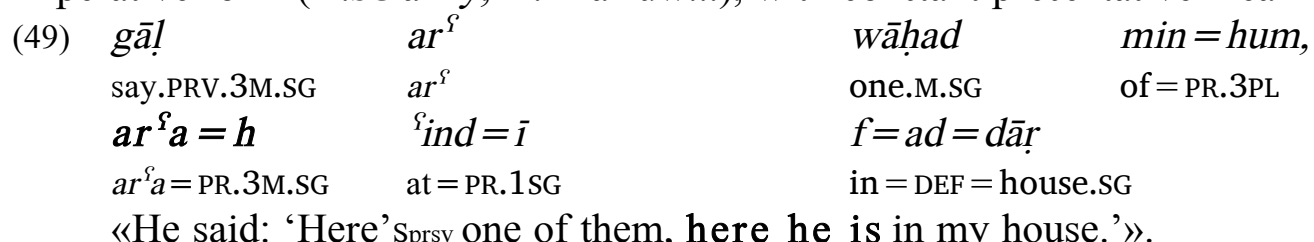

In the Northern Sinai, the vowel tends to vary from one locality to another, but $\operatorname{ir}^{\uparrow}(i)$ or $\operatorname{ar}^{\uparrow}(a / i)$ is used in most dialects as a presentative particle, in particular to draw attention to someone or something (De Jong 2000: 235).

$$
\begin{aligned}
& \text { iri }^{\complement} \quad \text { ğizlān }=\bar{i} \\
& \text { iri }^{\text {S }} \quad \text { [the].wallet.[of] }=\text { PR.1SG } \\
& \text { «here's my wallet» }
\end{aligned}
$$

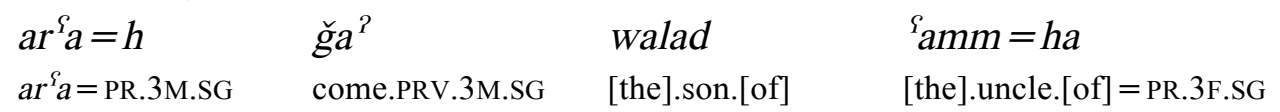


«there her cousin came»

$$
\begin{aligned}
& \operatorname{ar}^{\Upsilon} \mathrm{i}=h \quad \text { zari }^{\complement}=n a \quad b=i \text {-șìr } \quad \text { xașāb } \\
& \operatorname{ar}^{\mathcal{S}_{i}}=\text { PR.3M.SG [the].crops.M.SG.[of] }=\text { PR.1PL PART }=3 \mathrm{M}-\mathrm{IPRV} . \text { become.SG fertile.M.SG } \\
& \text { «see (it) our crops become fertile» }
\end{aligned}
$$

\subsubsection{Mauritania: $r \bar{a}^{\Upsilon} \boldsymbol{i}$}

The Hassāniyya dialect seems to be the only North African dialect where a particle with a pharyngeal consonant is used. It is an invariable presentative particle $r \bar{a}^{-} \hat{\imath} /$ $\operatorname{ar}^{-} \overline{\hat{\imath}} \hat{i}$, of the monstrative type, which is clearly distinct in its uses from the particle rā-. When it is followed by a noun (definite or indefinite), it serves as a predication auxiliary and is not followed by a pronoun:
rấ $\hat{i}$
xrûv
$r \bar{a}^{-\hat{\beta}} \hat{i}$
lamb.M.SG
'Here is a lamb!'

However, when it is followed by a verb, the presence of a pronoun affix is mandatory. ${ }^{16}$ The verb, which in this case expresses simultaneity, is usually in the participial form: ${ }^{17}$

(54) $r \bar{a} \hat{\imath} \hat{\imath}=h$

žây

$r \bar{a}^{\hat{\varsigma} \hat{\imath}}=$ PR.3M.SG

come $=$ PTCP.M.SG

'He is coming'

(a) $r \bar{a} \bar{a}^{\hat{1}}$ has the imperative pattern of a verb derived with a first long vowel $\bar{a}$. In Hassāniyya, in the stead of ${ }^{*} \operatorname{ra}^{-} a$, one finds the basic verb form $r^{\Upsilon_{a}}$ yar ${ }^{\Upsilon^{\Upsilon}} a(+$ preposition vo 'in') which means 'look, observe, watch', the action noun of which is $\operatorname{trâ}^{\uparrow} i$ (Taine-Cheikh 1988-98: 795). The particle, like the verb, appears to both be linked to the root $\mathrm{R}^{\uparrow} \mathrm{Y}$ from which also derive $r \bar{a}^{\Upsilon} \bar{a}$ 'to supervise, watch' and $r \bar{a}^{\Upsilon}$ in 'shepherd' in Classical Arabic. Even though the particle is not directly linked to this root, it is nonetheless possible that its evolution happened under its influence. ${ }^{18}$

\subsection{Particles with initial $t$}

We will distinguish two groups, according to the final vowel. Only the first group is unanimously considered as derived from * $r a^{2} \bar{a}$ 'see', the $t$ - being interpreted as the marker of the second singular person of the prefixed conjugation ( $=$ 'you see').

\subsection{1. $\operatorname{tara}(a) / \operatorname{tra}$}

As Fischer highlights (ibid:: 195), the meanings of tarā are also varied: at times they are indicative, sometimes modal - as is the case with the prefixed conjugation in Arabic.

a) Presentative and assertion modality

Palva notes that, in a poem heard in al-Balqa $\hat{a}^{\mathrm{S}}$, the presentative used is not har ${ }^{\complement} \mathrm{i} /$ hari but $\operatorname{tar} \bar{a}(1992:$ 70, 129):
(55) $\operatorname{tar} \bar{a}=k u$
kasbān-īn
$\operatorname{tar} \bar{a}=$ PR.PL get.the.victory.PRCP.M.PL
"Look, it's you who have won the victory.»

In general however, tarā is mostly used in dialects where other particles $\left(r \bar{a}, r a^{\uparrow}\right.$, (ha) $r^{\complement}$ a...) are not used.

Hence tarā is used in Western Sudan dialects, both as a presentative and as an

\footnotetext{
${ }^{16}$ The pronoun represents the agent bearing the monstration.

${ }^{17}$ More rarely, it is in the suffixed conjugaison (perfect tense) or in the prefixed conjugaison preceded by lāhi (imminent future).

${ }^{18}$ The lexicon derived from the root $\mathrm{R}^{\mathrm{S}} \mathrm{Y}$ is particularly important for the Bedouins and it is there that particles with pharyngeal consonants are the most widespread.
} 
assertive particle, possibly with constrictive meaning as in (58) in the Baggara dialect (Hillelson 1929 Nr. 3,2):

(56) $\operatorname{tar} \bar{a}=u$

$\operatorname{tar} \bar{a}=$ PR.3M.SG

«there he is!» (Lethem 1920: 456)

(57) $\operatorname{tar} \bar{a}=h u \quad l=b \bar{a} b$

$\operatorname{tar} \bar{a}=$ PR.3M.SG $\quad \mathrm{DEF}=$ door

«there is the door» (Trimingham 1946: 11)

$\begin{array}{lllll}\text { hattina }=n a & l=\text { ilfana } & \text { nihna } & \text { tara } & \text { haiji- } n \\ \text { destine.PRCP.M.PL= PR.1PL } & \text { for=destruction } & \text { we } & \text { tara } & \text { alive.M.PL }\end{array}$

«they destined us for destruction, behold we are alive»

Another area where it is used is in the East and North of the Arabic peninsula. Indeed, tarā is noted in Oman (Reinhard 1972: 379), Iraq (Altoma 1969: 99) and in several eastern Bedouin dialects, from the North of Saudi Arabia to Syria. ${ }^{19}$ tarā frequently appears at the beginning of an utterance and most often with a pronominal suffix. For example among the Rwala (Cantineau ibid.: 199):

(59) tarâ $=$ kom šăhed-în

$\operatorname{tar} \hat{a}=$ PR.2PL witness-M.PL

('vous êtes témoins') 'You are witnesses'

(60) tarâ $=$ kom gazu

tarâ $=$ PR.2PL ghazou.M.SG

('Voilà un ghazou'.) 'Here is a ghazou'.

According to Cantineau, for these Bedouins, tarā can have the meaning of a presentative, as in (60), but he considers that it often has the meaning of 'to be', as in (59). As for Landberg (ibid.: 489-492), who provides several examples of tarā among the Bedouins of the North ( ${ }^{\mathrm{S}}$ Anazeh in particular), he generally translates it by 'it is that' or 'there it is' which underlines the semantic proximity with the Southern Bedouins $\mathrm{ra}^{\text {S }}$.

Indications as to the particle's meaning can vary from one dialect to another, depending on its frequency, but perhaps also depending on the text under consideration or the author's point of view. Sowayan (1992: 251) presents the presentative particle tara/tar/taru as being highly frequent among the Sammar, and recognizes its use for drawing attention, similar to Classical Arabic inna. Bettini (2006: 47) stresses that tara lends assertive meaning, however she also refers to Talay (2003), who considers that it is not always necessary to translate the particle. In fact, it is probably necessary to avoid overgeneralizing, including when the issue is the presence or absence of the suffix pronoun. On these two perspectives, one may compare the following examples taken from the tales of the Syrian High Jezireh (Bettini, ibid:: 47):
(61)
$\operatorname{tar} \bar{a}=n i \quad a^{\complement} \bar{u} d$
$\Upsilon_{a l \bar{e}}=\check{c} i$
$\operatorname{tar} \bar{a}=\mathrm{PR} .1 \mathrm{SG}$
1.come.back.IPRV.SG
to $=$ PR.2F.SG

('(en lui disant: si c'est une fille) tu me verras revenir à toi') '(telling him: if it is a girl) you will see me come back to you' $(\mathrm{I}, 46)$
$\operatorname{tar} \bar{a}=u$
$m^{\Upsilon} a z \bar{u} m$
Sind $=i$
$\operatorname{tar} \bar{a}=$ PR.3M.SG invited.M.SG
at $=\mathrm{PR} .1 \mathrm{SG}$

('Il dit [...] il sera invité chez moi') '[He says/said...] he will be invited to my home' (XLVI, 23)

\footnotetext{
${ }^{19}$ But tarā is not only found in Bedouin dialects: see e.g. in Bīr Zēt (Blau 1960: 203).
} 


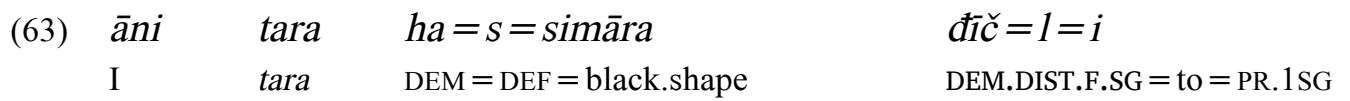

('[Il dit:] cette forme noire sera à moi') '[He says/said...] this black shape will be mine' (XXVI, 2)

In some dialects, tarā is not found at the beginning of the utterance but is «used as a parenthetical expression before a verb or a noun» (Altoma ibid.). In such cases, in Irak (Woodhead \& Beene 1967: 55) as well as in Bahrain (Holes 2001: 195), it takes on the meaning of 'you see, mind you', or, between two clauses, the alternative meaning of 'or, otherwise', or the causal meaning 'since, because'. ${ }^{20}$

b) Non assertive modal particle

The uses of tarā are more limited in some dialects, sometimes they are solely modal. We have found at least four distinct uses for the particle, which tends to be used on its own (without a pronoun) or preceded by ya. Such utterances are exclamatory or interrogative.

i) In Chadian Arabic, tara is an invariable interjection which means 'that's enough! stop it! careful!' and is used to express exasperation (Jullien de Pommerol 2000: 1184): (64)

$\begin{array}{lllll}\begin{array}{l}\text { Hêy } \\ \text { hêy }\end{array} & \text { wilêd } & \text { agôd } & \text { sâkit } & \underline{\text { tara! }} \\ \text { child.SG } & \text { stay.IMP.M.SG } & \text { be.quiet.PRCP.M.SG } & \text { tara }\end{array}$ enough!'
('Hé! l'enfant! reste tranquille, cela suffit!') 'Hey! Child! Be quiet, that's

ii) In Egypt, ya tara is used for expressing doubt. Badawi and Hinds (1986: 321), who also note the variant ya hal tara, give an example where the particle is found in sentence final position:

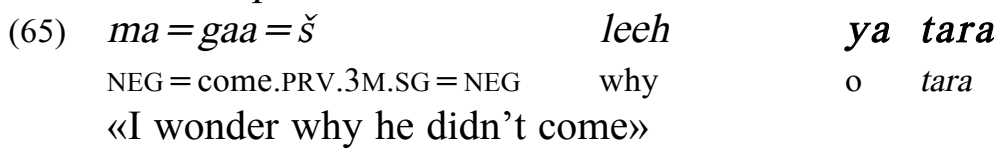

According to Woidich (2006: 362), in Cairo ya tara is used sentence initially or finally, and can combine with interrogative adverbs such as min:
(66) $y$
tara
Hasan
mawgūd
o tara
Ḥasan
be.found.PRCP.PAS.M.SG

('ist Hasan da ?') 'Is Hasan there?'

$\begin{array}{llll}\text { ya } & \text { tarra } & h a=y k u \bar{n} & \text { mīn? } \\ \text { o } & \text { tara } & \text { ha }=3 \text { M.IPRV.be.SG } & \text { who }\end{array}$

('wer das wohl sein wird ?') 'Who will that be?'

In Damas ya tara (or ya hal tara in sentence initial position) has the same connotations of doubt (Salamé \& Lentin, forthcoming):

$\begin{array}{cll}\text { (68) ya tara } & \text { ?əja ? } \\ \text { ô } & \text { tara } & \text { arrive.PRV.3M.SG }\end{array}$

('Tu crois qu'il est arrivé ?) 'Do you think he has arrived?'

iii) But tara (without ya) can also be used in Damas with the meaning of 'you will see', with threatening overtones:

(69) tara

$$
b=\partial \underline{d}^{p} r b=a k
$$

tara

$$
\mathrm{PART}=\text { hit.IPRV.1SG }=\text { PR.2SG }
$$

('Tu vas voir, je vais te frapper, moi!') 'just you wait, I'm going to hit you!'

iv) Finally the form trâ is noted in Tunisia with the hortatory sense of 'come on!': in

\footnotetext{
${ }^{20}$ One should note that it can have additional meanings, e.g. with modal coloring: 'it seems, looks like' or 'I tell you, I warn you'.
} 
Takroûna (Marçais \& Guiga 1958-61: 1404) and in Gabès, where trâa(h) has the plural form trâhu, acquired by analogy with the imperative (Marçais \& Fares 1931: 222).

\subsubsection{From (a)tāari to tari/tāri}

Although tari/tāri appears formally and semantically similar to the particles seen above, particularly tara/tarā, some of its uses show its similarity to particles having an interdental first radical. Landberg (ibid: 194 - in Wetzstein, ZDMG, XXII: 123) believes that such variants could derive from the plural of ' $t r$ 'trace'. He adds that atāri is only one prononciation for atāri and that tāri has simply lost its initial a. The most recent data inventory strengthens this hypothesis.

a) Forms with an interdental consonant

These are absent from the Southern dialects of the Arabic peninsula (Landberg ibid.: 495), and appear to be found only in the Bedouin dialects in the North. ${ }^{21}$ Sowayan (ibid.: 244) identifies no fewer than five variants (ațir, ațāri, tāri, atāari and tari) - for seven tokens - in the oral traditions of the Šammar, but all with the same meaning:

«In its various phonetic manifestations which are freely distributed this particle expresses sudden realization, counter expectation, surprise or regret. It either introduces the subject of a sentence [...] or, if not followed by the subject directly, takes a pronominal suffix which agrees with the subject».

Henkin (2010: 134, 141) notes four variants in Negev Arabic (itrāāt), itrīt, tarìt and atariy). These forms are quite divergent and some show etymological kinship with the lexeme ' $-\underline{t}-r$ 'footsteps, tracks'. The author considers that such particles are presentatives, like $a r^{\complement}$ and hay 'look here', and that her second subcategory of particles are 'presentatives of conversational discourse'. ițrāt, itrīt and tarīt are 'evidential presentatives' which appear both in spontaneous discourse and in storytelling. ${ }^{22}$ At times Henkin translates them by 'apparently', at others by 'it turns out that' because, based on evidentiality, she perceives a combination of several modal concepts:

(i) noncommitment to the information, which is secondhand knowledge

(ii) findings contrary to expectations

b) Forms with a dental consonant

For Landberg (ibid.: 492-3), forms with a dental consonant, with or without initial a-, are characteristic of Cairo and very much so of Damas. In his inventory, Fischer (ibid.: 197-8) also quotes Khartum and Shuwa. Below are some examples related to these particles, taken from recent work. ${ }^{23}$

In Damas, tāri means 'and there it goes' (on a proven but improbable event, one that is unexpected, or had simply been unknown until then), 'and there it shows that, there it looks like, there I discover that etc.' (Salamé \& Lentin, forthcoming):

$\begin{array}{lll}\text { (70) tāri aḥmad } & \text { msāfer } \\ \text { tāri ahmad } & \text { travel. PRCV.M.SG }\end{array}$

('j'ai appris que [contrairement à ce que je pensais] Ahmed est parti'.) 'I learnt that [contrary to what I thought] Ahmed is gone'.

\footnotetext{
${ }^{21}$ Further study would probably reveal other more or less comparable uses, such as Mauritanian etr(u)... 'it seems that (he/it), it would be that (he/it)...', literally 'trace (of he/it)' (Taine-Cheikh 198898: 7).

${ }^{22}$ The third subcategory of presentatives («presentatives of narrative discourse, such as ( $\left.\dot{g} \bar{a} r\right)$ win, wlin, willa, illa $W$ 'and lo'») does not concern us here.

${ }^{23}$ We cannot confirm the uses of these particles in Cairo (there is no mention of them in Woidich's grammar).
} 
In Chadian Arabic (Jullien de Pommerol ibid.: 1188), the meaning of târi is quite broad: 'maybe that, or, there it is'. In example (71) it introduces an exclamation coupled with interrogation.

(71) târi, kan mâ

târi if NEG

inta mâ jâyi

macê-na $\quad l \hat{e}=k$,

you NEG come.PRCP.M.SG

go.PRV-1PL for $=$ PR.2.SG

$l \hat{e}=n a !$

('Si nous n'allions pas chez toi [si nous ne sommes pas allés chez toi], tu ne viendrais pas chez nous!') 'If we were not going to your place [if we did not go to your place], you would not come to ours'

In Sudanese Kordofan Arabic (Kordofanian Baggara Arabic), tarí has the meaning of 'so, then, afterwards': "It is basically used as a discourse connector but it also has some pragmatic value since it recalls the attention of the hearer on a single constituent of the sentence" (Manfredi 2010: 212).

$$
\begin{aligned}
& \text { wokit dāk ana } m a^{\complement} \quad a m m=1 \quad d \bar{o} 1 \\
& \text { time DEM.DIST.M.SG I with [the].mother.[of] = PR.1SG DEM.PROX.M.PL } \\
& \text { tarí șahí } k a l a ̄ m=k i \\
& \text { tarí right.M.SG [the].discourse.[of] = PR.2F.SG } \\
& \text { «At that time I was with the family of my mother - You are right» } \\
& \text { tarí addi }=n i ́ \quad l \bar{e}=h a \\
& \text { tarí give.IMP.SG }=\text { PR.OBL.1SG for }=\text { PR.3F.SG }
\end{aligned}
$$

\section{3. rayt, ya rayt}

Some particles derive from the suffixed inflection of the verb 'to see' $\left(\mathrm{ra}^{\mathrm{P}} \bar{a}\right)$, in the $1^{\text {st }} / 2^{\text {nd }}$ singular. It is quite frequently used, and is found in Eastern Maghreb as well as in the Middle-East. It usually expresses wishes.

Syrian yā rêt (Cowell 1964: 350) and Cairo Egyptian yarēt (Woidich ibid.: 369) are particles indicating a wish ('would that, I wish'). The same holds for $y \bar{a} r \bar{e} t$ in Tripoli, in Western Libya (Pereira 2010: 442):

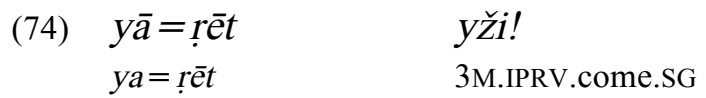

('Ah pourvu qu'il vienne!') 'Oh, hopefully he will come!'

In Eastern Libyan dialects, ya rayt "expresses a wish by the speaker for a condition other than what currently obtains (conterfactual)" (Owens 1984: 146):

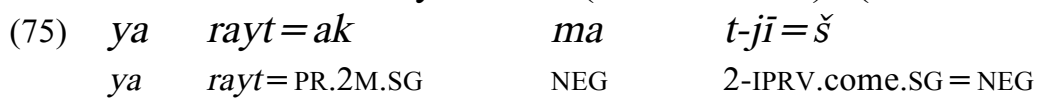

«If only you weren't coming.»

(76) ya rayt $=n i \quad$ gani

ya rayt $=$ PR.1SG rich.M.SG

« Would that I were rich!»

Finally, in Tunisia, it must be noted that this expression of a wish is not widespread. It is noted in Takroûna, where ia-rrâa serves as a hortatory optative particle (Marçais \& Guiga ibid.: 1404). However, rêt (+ pronoun suffix) is used by the Marazig to express regret (Boris ibid.: 197):

(77) âh! rêt $=$ na métna fe $=h \bar{a} k \quad l=$ aiyâm!

âh $r e ̂ t=$ PR.1PL die.PRV-1PL in = DEM.DIST $\quad$ DEF $=$ day.PL

('hélas! que ne sommes-nous morts en ce temps-là') 'Alas! Why did we not die at that time' 


\section{4. $\check{s a}^{9}$}

After studying the various uses of particles derived from $\mathrm{ra}^{\mathrm{P}} \overline{\mathrm{a}}$ 'to see', Landberg (ibid.: 496-7) notes the uses of the particle $\check{s}^{\Upsilon}$. He gives a series of examples collected from the Datīna, where he generally translates $\check{s}^{\S}$ by 'because'. It is not certain that the explanatory value is common to all dialects where $\check{s}^{\mathcal{S}}$ is found, since, in Damas for example, it is only used as a presentative particle, as in the following example (Stowasser \& Ani 1964: 115):
(78) $\check{S} a^{\complement}=O$
$1={ }^{\circ} \mathrm{ktaab}$
$\check{s} a^{q}=$ PR.3M.SG
$\mathrm{DEF}=$ book.M.SG
«here's the book»

That being said, the particle $\check{s}^{\S}$, in use in several dialects (e.g. Lebanon, Syria, Datînah), shows similarities with other particles as it is «a shortened form of the imperative for the verb qaša ${ }^{\S}$ 'to see'» (Khan 2008: 705). ${ }^{24}$

\section{Conclusion}

The example of $\check{s}^{\S}$ shows, if indeed such demonstration is necessary, that verbs meaning 'see' in Arabic have a strong tendency to grammaticalize. One might believe this to be quite common crosslinguistically, however the fact that very few instances of this grammaticalization are found by Heine \& Kuteva (2002: 269$270)^{25}$ shows that this hypothesis would be unfounded; it further shows that the study of the data from Arabic is all that much more worthwhile.

The grammaticalized forms presented here are mostly presentative or expressive forms. Presentatives may serve as simple 'pointers' or as presentation auxiliaries. The expressive markers indicate a certain stance or attitude on the speaker's part, either as concerns the utterance as a whole (insistence, evidentiality — shouldering responsibility or not for the information presented-, wishes or regrets...), or as concerns defining a given fact's importance (in relation to the time of speech or to other information provided). They are tools used to select or insist on a given element, event or interclausal relation, and are frequently, but not exclusively, found in discourse (where intonation often plays a determining role). Finally, in a few rare cases, their expressiveness tends to bleach so that they serve as simple copulas.

Alongside $\check{s} a^{\Re}$, we have grouped all of the other forms into five series, depending on their (more or less close) kinship to * ra $\bar{a} \bar{a}$ 'see': I. ra(a) II. (a)ra ${ }^{\varsigma}$ III. tara(a) IV. ta(a)ri V. (ya) rayt. Their geographic distribution varies widely. While ra(a) is found only in the Maghreb, the other series are found only outside of the Maghreb (with a very few exceptions such as ḥassāniyya (a) $\mathrm{ra}^{\mathcal{S}}$ and Tunisian tara(a)).

Their meanings also show differences, which might partially be explained - albeit only partially - by the probable mixed origins of (a)ra ${ }^{\S}$ and ta(a)ri (origins contaminated for the former by the root $r \bar{a}^{-} a$ 'watch, guard', and for the latter by the root 'atr 'trace (of)').

Whereas (a)ra ${ }^{\uparrow}$, and more particularly $\check{s}^{\uparrow}$, are essentially (or exclusively) presentatives, ta(a)ri and (ya) rayt serve mostly as discourse particles. ra(a) and tara(a), tend to be used in very similar ways. In some dialects their use is widespread, including as simple copulas. In others, they only serve a limited number of the possible uses, and are usually used as presentatives or as modals, leaving one of the other series to cover the other uses (see e.g. the case of rā vs. $r \bar{a}^{\hat{S}_{i}}$ in hassāniyya, or tara vs. $a r^{\complement} a$ in the Negev).

\footnotetext{
${ }^{24}$ On the verb qaša ${ }^{\uparrow}$, see Borg 2004: 388.

${ }^{25}$ SEE > (1) ALLATIVE. (2) PASSIVE.
} 
Given that $\mathrm{ra}(\mathrm{a})$ is found throughout the Maghreb (and only there), one could consider it a characteristic trait of Northern African Arabic. However, the diversity of the trait's manifestations in the Maghrebian dialects on the one hand, and the similarities between Maghrebian ra(a) and 'Middle-Eastern' tara(a) on the other hand, show that this trait is far from useful for purposes of distinction.

The current study, which builds on previous studies and would certainly benefit further from more in-depth studies on specific points, highlights not a faultline, but rather several continua (in terms of both form and meaning). Some convergences demonstrate kinship among geographically contiguous areas whereas others (such as the use of $\mathrm{ra}^{\Re}$ ) can apparently only be explained through much older kinships of a socio-historical nature.

\section{References}

Altoma, Salih J. 1969. The Problem of Diglossia in Arabic: a Comparative Study of Classical and Iraqi Arabic. London: Oxford University Press.

Badawi, El-Said and Hinds, Martin. 1986. A Dictionary of Egyptian Arabic. Arabic-English. Beirut: Librairie du Liban.

Bauer, Leonhard. 1926 (1 ${ }^{\text {st }}$ ed. 1910). Das Palästinische Arabisch. Die Dialekte des Städters und des Fellachen. Hinrichs: Leipzig.

Bettini, Lidia. 2006. Contes féminins de la Haute Jézireh syrienne. Matériaux ethno-linguistiques d'un parler nomade oriental. Firenze: Università di Firenze.

Blau, Joshua. 1960. Syntax des Palästinenischen Bauerndialekts von Bīr Zēt. Auf grund der "Volkserzählungen aus Palästina” von Hans Schmidt und Paul Kahle. Walldorf-Hessen: Verlag für Orientkunde Dr. H. Vordran.

Bloch, Ariel, 1993. Verbs of topographical elevation, the case of $\check{s} \bar{a} f$ 'to see' in colloquial Arabic. Zeitschrift für Arabische Linguistik 25, 100-107.

Borg, Alexander. 2004. Comparative Glossary of Cypriot Maronite Arabic (Arabic-English). With an Introductory Essay. Leiden-Boston: Brill.

Boris, Gilbert. 1958. Lexique du parler arabe des Marazig. Paris: Klincksieck.

Boucherit, Aziza. 2002. L'arabe parlé à Alger. Aspects sociolinguistiques et énonciatifs. ParisLouvain: Peeters.

Cantineau, Jean. 1936-1937. Etudes sur quelques parlers de nomades arabes d'Orient. I. AIEO 2, 1118. II. AIEO 3, 119-237.

Caubet, Dominique. 1992. Deixis, aspect et modalité, les particularités $h \bar{a}$ - et $r \bar{a}$ - en arabe marocain. In Marie-Annick Morel and Laurent Danon-Boileau (eds.), La deixis 139-49. Paris: P.U.F.

Caubet, Dominique. 1993. L'arabe marocain. Louvain: Peeters.

Cohen, David. 1962. 'Koinè', langues communes et dialectes arabes. Arabica IX/2, 119-144.

Cohen, David. 1963. Le dialecte arabe hassānīya de Mauritanie. Paris: Klincksieck.

Cohen, David. 1984. La phrase nominale et l'évolution du système verbal en sémitique. Etudes de syntaxe historique. Paris: Société de Linguistique de Paris.

Cohen, David. 1989. L'aspect verbal. Paris: P.U.F.

Cohen, Marcel. 1924. Le système verbal sémitique et l'expression du temps. Paris: Leroux.

Colin, Georges S. 1939. Chrestomatie marocaine. Textes citadins en transcription latine. Paris: Adrien Maisonneuve.

Colin, Georges S. 1963. Quelques calques syntaxiques et sémantiques sur le berbère dans les parlers arabes du Maghreb (séance du 22 décembre 1948). Comptes rendus du GLECS (1960-1963, i.e. 1948-1951) $V$, 4-8.

Colin, Georges S. 1966. La proposition nominale en arabe marocain (séance du 11 mai 1966). Comptes rendus du GLECS (1963-1966) X, 173-175.

Cowell, Mark W. 1964 [re-ed. 2005]. A Reference Grammar of Syrian Arabic. Washington D. C.: Georgetown University Press.

De Jong, Rudolf. 2000. A Grammar of the Bedouin Dialects of the Northern Sinai Littoral: Bridging the linguistic gap between the eastern and Western Arab world. Leiden: Brill.

Driver, Godfrey R. 1925. A Grammar of the colloquial Arabic of Syria and Palestine. London: Probsthain.

Ferguson, Charles. 1959. The Arabic Koinè. Language 35/4, 616-630.

Fischer, Wolfdietrich. 1959. Die demonstrativen Bildungen der neuarabischen Dialekte: Ein Beitrag zur historischen Grammatik des Arabischen. s'-Gravenhage: Mouton and Co.

Grand'Henry, Jacques. 1995. Conservation and change in Algerian Bedouin Arabic. In Joe Cremona, 
Clive Holes and Geoffrey Khan (eds.), Proceedings or the 2nd International Conference of L'Association Internationale pour la Dialectologie Arabe 51-57. Trinity Hall (University of Cambridge), 10-14 sept. 1995.

Harrell, Richard S. 1962. A Short Reference Grammar of Moroccan Arabic. Washington D. C.: Georgetown University Press.

Heine, Bernd and Kuteva, Tania. 2002. World Lexicon of Grammaticalization. Cambridge: Cambridge University Press.

Henkin, Roni. 2010. Negev Arabic. Dialectal, Sociolinguistic, and Stylistic Variation. Wiesbaden: Harrassowitz Verlag.

Hillelson, S. 1929. Songs of the Baggara. Sudan Notes and Records 12, 73-83.

Holes, Clive. 2001. Dialect, Culture and Society in Eastern Arabia. Volume 1. Glossary. Leiden: Brill.

Jullien de Pommerol, Patrice. 2000. Dictionnaire de l'arabe tchadien. Paris: Karthala.

Kaye, Alan S. 1976. Chadian and Sudanese Arabic in the light of comparative Arabic dialectology. The Hague-Paris: Mouton.

Kaye, Alan S. 1986. The Verb 'See' in Arabic Dialects. In Joshua A. Fishman, Andree TabouretKeller, Michael Clyne, Bh. Krishnamurti and Mohamed Abdulaziz (eds.), The Fergusonian Impact: In Honor of Charles A. Ferguson on the Occasion of His 65th Birthday, I: From Phonology to Society; II: Sociolinguistics and the Sociology of Language 211-222. Berlin: Mouton de Gruyter.

Khan, Geoffrey. 2008. Presentatives. In Alaa Elgibali Mushira Eid, Kees Versteegh (editor-in-chief), Manfred Woidich \& Andrzej Zaborski (eds), Encyclopedia of Arabic Language and Linguistics 703-705. Leiden: Brill.

Landberg, comte Carlo de. 1909. Etude sur les dialectes de l'Arabie Méridionale. II. Datînah (2). Leiden: Brill.

Lethem, Gordon J. 1920. Colloquial Arabic, Shuwa dialect of Bornu, Nigeria and of the region of Lake Tchad. London: The Crown Agents for the Colonies.

Manfredi, Stefano. 2010. A Grammatical Description of Kordofanian Baggara Arabic. Tesi di Dottorato in Africanistica. Dipartimento di Studi e Ricerche su Africa e Paesi Arabi Napoli: Università degli Studi di Napoli "L'Orientale".

Marçais, Philippe. 1956. Le parler arabe de Djidjelli (Nord Constantinois, Algérie). Paris: Maisonneuve.

Marçais, Philippe. 1975. 'Arabiyya III. - Les dialectes arabes. 3. - Les dialectes occidentaux. Encyclopédie de l'Islam (2 ${ }^{\text {nd }}$ ed.) 597-601. Leiden-Paris: Brill-Maisonneuve \& Larose.

Marçais, William. 1911. Textes arabes de Tanger. Paris: Leroux.

Marçais, William and Farès, Jelloûli. 1932. Trois textes arabes d'El-Hâmma de Gabès (suite). Journal Asiatique CCXXI (1932 oct.-déc.), 193-269.

Marçais, William and Guiga, Abderrahmân. 1958-61. Textes arabes de Takroûna, II. Glossaire. Paris: Geuthner.

Owens, Jonathan. 1984. A short reference grammar of Eastern Libyan Arabic. Wiesbaden: Harrassowitz.

Palva, Heikki. 1980. Characteristics of the Arabic Dialect of the Bani Saxar Tribe. Orientalia Suecana 29, 112-139.

Palva, Heikki. 1992. Artistic Colloquial Arabic. Traditional narratives and poems from al-Balqâ $\hat{A}^{\varsigma}$ (Jordan): transcription, translation, linguistic and metrical analysis. Studia Orientalia 69, $191 \mathrm{p}$.

Pereira, Christophe. 2010. Le parler arabe de Tripoli (Libye). Zaragoza: Instituto de estudios Islámicos. Estudios de Dialectología Árabe.

Reinhardt, Carl. 1972 ( $1^{\text {st }}$ ed. 1894). Ein arabischer Dialekt gesprochen in ${ }^{\varsigma}$ Omān und Zanzibar. Amsterdam: Philo Press.

Rhodokanakis, Nikolaus. 1908. Der vulgärabische Dialekt im Dofâr (Zfâr). I. Prosaische und poetische Texte. Wien: Hölder.

Salamé, Claude and Lentin, Jérôme. forthcoming. Lettre $R$ du dictionnaire d'arabe de Damas [Personal communication].

Sowayan, Saad Abdullah. 1992. The Arabian Historical Narrative. An Ethnographic and Linguistic Analysis. Wiesbaden: Harrassowitz.

Stewart, Frank H. 1990. Texts in Sinai Bedouin Law, Part 2. Texts in Arabic. Wiesbaden: Harrassowitz.

Stowasser, Karl and Ani, Mokhtar. 1964. A Dictionary of Syrian Arabic: English-Arabic. Washington D. C.: Georgetown University Press.

Stumme, Hans. 1896. Grammatik des Tunisischen Arabisch nebst Glossar. Leipzig: Hinrichs.

Stumme, Hans. 1898. Märchen und Gedichte aus der Stadt Tripolis in Nordafrika. Leipzig: Hinrichs.

Taine-Cheikh, Catherine. 1988-98. Dictionnaire Hassaniyya-Français. 8 volumes. Paris: Geuthner. 
Talay, Shabo. 2003. Der arabische Dialekt der Khawētna. Teil II: Texte und Glossar. Wiesbaden: Harrassowitz.

Tauzin, Aline. 1993. Contes arabes de Mauritanie. Paris: Karthala.

Trimingham, J. Spencer. 1946. Sudan colloquial Arabic. London: Oxford University Press.

Vanhove, Martine. 1995. Les particules qad et $r a^{\varsigma}$ dans un dialecte arabe de la région de Yâfi ${ }^{\varsigma}$ (Yémen). In Joe Cremona, Clive Holes and Geoffrey Khan (eds.), Proceedings or the 2nd International Conference of L'Association Internationale pour la Dialectologie Arabe 24352. Trinity Hall (University of Cambridge).

Vanhove, Martine. 2010. Deixis, information structure and clause linkage in Yafi ${ }^{\varsigma}$ Arabic (Yemen). In I. Bril (ed.), Clause Linking and Clause Hierarchy. Syntax and pragmatics 333-354. Amsterdam / Philadelphia: Benjamins.

Woidich, Manfred. 2006. Das Kairenisch-Arabische. Eine Grammatik. Wiesbaden: Harrassowitz.

Woodhead, D. R. and Beene, Wayne. 1967. A Dictionary of Iraqi Arabic: Arabic-English. Washington D. C.: Georgetown University Press. 